\title{
CrossRef : 未来に向けて
}

\author{
CrossRef: Towards the future
}

BRAND, Amy ${ }^{1}$ 熊谷玲美 ${ }^{2}:$ 訳

\section{1. はじめに}

こんにちは。お集まりいただきありがとうござ います。ここに来ることができて光栄です。この セミナーを準備していただいたJSTとJ-STAGEの皆 さんに感謝いたします。ここ 3,4 年, 皆さんと一 緒に㗢くことができて, とても嬉しく思っていま す。私たちは非常に生産的な関係を保っていると 思います。

本日の講演の目的は 2 つあります。 1 つ目は, CrossRefの概要と最新の状況をお話しすることで す。CrossRefやDOIについてよく知っている方も, そうでない方もいらっしゃると聞いていますので, どちらの方にも興味ある情報, また理解できる情 報をご紹介したいと思います。

もう1つの目的は, CrossRefのメンバーである出 版社の事例をご紹介することです。CrossRefは, 開 始以来約7年で, 特に国際的な学術出版社のため の, 非常に優れた共有デジタル・インフラストラ クチャーになっています。同種の取り組みの中で は, 最も成功しています。そこで, CrossRefが成功 した理由についてお話ししたいと思います。

\section{CrossRefとDOIの概要}

\section{1 境界を越えて}

CrossRefの物語は, 情報源の間, さらには国の間 の境界 (CrossRefは非常に国際的な組織なので) を 克服することで, 情報源の相互連結性を実現させ る物語です。個人的には,これはより大きなビジョ

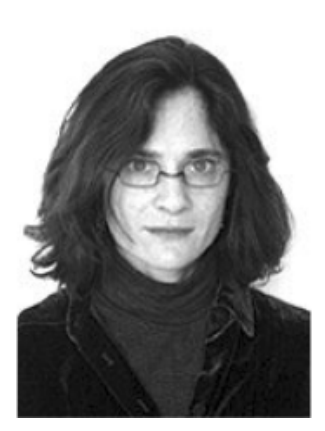

BRAND, Amy氏 略歴

2001年4月にCrossRefに加わる。現在ビジネス・製 品開発部長。出版社, 図書館, ベンダーによる CrossRefリンキング技術の採用の増加, ならびに 新しいCrossRefサービスの開発に関与。職歴は, 電子出版, 書籍出版, 研究と幅広い。MITで認知 科学の博士号を取得後, Ingenta, Lawrence Erlbaum Associates, The MIT Press, およびペンシルベニ ア大学に勤務。学術出版学会 (Society for Scholarly Publishing) 運営委員会委員, および経営懇談会 共同議長。業界イベントでの講演多数。またJournal of Electronic Publishingの編集委員。

ンの一部だと思っています。なぜこれが重要で, 興味深いのでしょうか。

研究活動を行う人々 (私もかつて研究者でした) や, 学術出版に携わる人々は, 現在が歴史的に見 て, 非常におもしろい時期だと気づいていると思 います。情報資源のデジタル化, 相互リンク, Google などによる全文検索サービス用のインデックス付

${ }^{1}$ CrossRefビジネス・製品開発部長

${ }^{1}$ Director of Business and Product Development, CrossRef/PILA (40 Salem Street, Lynnfield, MA 01940, USA)

E-mail: abrand@crossref.org

2 科学技術振興機構『情報管理』編集事務局気付（干102-8666東京都千代田区四番町5-3） E-mail: remy@mtg.biglobe.ne.jp

2 c/o JOHO KANRI Editorial office, Japan Science and Technology Agency (5-3 Yonban-cho Chiyoda-ku, Tokyo 102-8666)

本稿は, 2007年7月5日に開催されたJ-STAGEセミナー「CrossRefとOpenURL : リンクで広がる学術情報流通の現 在」(p.549参照) での講演を, 編集・翻訳したものである(『情報管理』編集事務局文責)。 
与などが行われており,これによって分野を越え た研究上の発見が可能になっているからです。数 百年も昔のコンテンツも数多くデジタル化され, 保管されているので, 時間を超えた発見をするこ とさえあり得ます。デジタル化されるコンテンツ も多様化しています。私たちは, ジャーナル記事 だけではなく（現在はそれが中心にはなっていま すが）書籍やデータ, 研究論文, さらには画像も 対象としています。現在は非常に面白い時代です。 そして, CrossRefはまさにその中心にあります。こ の中でのCrossRefの主な役割は，いくつかの技術 的障壁および組織的障壁を低くして，この成長し つつある,相互にリンクした研究情報のネットワー クへ, もっと多くのコンテンツが参加できるよう にすることです。

CrossRefについてお話しする場合，「リンク切れ （link rot）」というものについてお話しすることに もなります。このおかしな作り物の「Error 404」の 標識をご覧ください（図1）。1990年後半, 学術出 版社がジャーナルをオンライン化し始めた頃に, CrossRefが設立された理由のひとつとして, 学術 コミュニケーションでは, リンク切れの問題は単 なるイライラの原因では済まないということがあ りました。研究活動は, 引用関係と, 誰が著者か ということが基盤になっており, 学術出版社は, 発行した記事のリンクが機能しないのは我慢でき なかったのです。これは，インターネットの情報 ではいまだに続く問題です。おなじみのWikipedia の数字を紹介しましょう。これは新しいオープン・ リソースですが, Wikipedia自身の説明では, 記事 内のリンクの約10\%が機能していないということ です。しかし, 学術文献の世界では, CrossRefの存 在が大きいのですが, 完全ではないにしろ大部分 ではリンク切れの問題を克服できています。そし てこれは, DOI（デジタル・オブジェクト識別子, digital object identifier）のおかげなのです。

\subsection{DOIの普及}

皆さんの中には, DOIについて詳しい方も, そう でない方もいると思いますので, DOIとは何かを 説明したいと思います。DOIというのは単なるひ とつの名前です。文字と数字からなる文字列で, 2 つの機能を持っています。ひとつは, 1 編のオンラ インコンテンツに対する固有の名前としての機能, もうひとつは, そのコンテンツのインターネット 上の場所への, 持続的で安定したリンクとしての 機能です。この持続性が実現するのは, DOIが,ディ

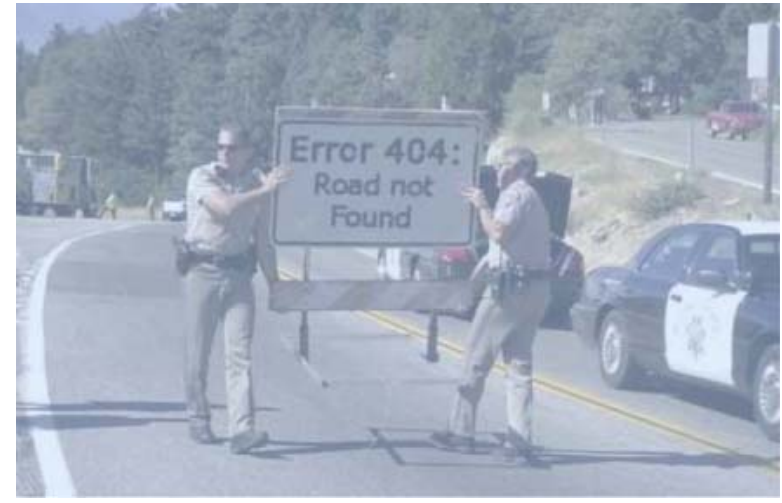

図1

レクトリ内で現在のアドレスを検索することだけ を行うからです。このディレクトリは，管理や更 新を行う必要があり,そこでCrossRefなどのDOI登 録機関が登場します。これは非常にシンプルな, リダイレクトという考え方です。これについては さらに少しお話ししたいと思います。

この技術に関連する組織の全体像をご覧くださ い（図2）。この技術自体は,「DOIハンドル・シス テム」と呼ばれており, 米国のCorporation for National Research Initiatives（CNRI）が始めたものです。Bob KahnはTCP/IPプロトコルの共同発明者の一人です が, 彼がこのシステムを開発しました。DOIは, 国 際DOI財団 (International DOI Foundation: IDF) が運 営しています。IDFはDOI標準の開発と管理を行い, そして先ほど述べた持続性を実現するための仕組 みを生み出しています。CrossRefは, 現在世界中に 8つあるDOI登録機関のなかで最大の規模を持ち, 最も長い歴史があります。最近活動を開始したDOI 登録機関に, 中国のWanfang Dataがありますが, Wanfang Dataでは, 中国語資料にDOIを割り当てる 計画があり, CrossRefはこの機関と密接に協力す ることを考えています。また，図2の上部には，ず らりと組織が並んでいますが, これには出版社だ けでなく, データベースや, その他の二次的サー ビス, このネットワークに参加している検索サー ビスが含まれます。こういった組織はさまざまな 形でこの技術を利用しています。

リンキングについてご説明しましょう(図3)。皆 さんは既に, ハイパーリンクをクリックして, リ ンクした別のコンテンツへと進むということを経 験していると思います。ここでは, これを少し変 形させています。それは, CrossRefの場合, リンク する先は記事全文ではなく, PubMedのようなアブ ストラクトの場合もあるからです。CrossRefのDOI リンクでユニークなのは，もし記事のフルテキス 


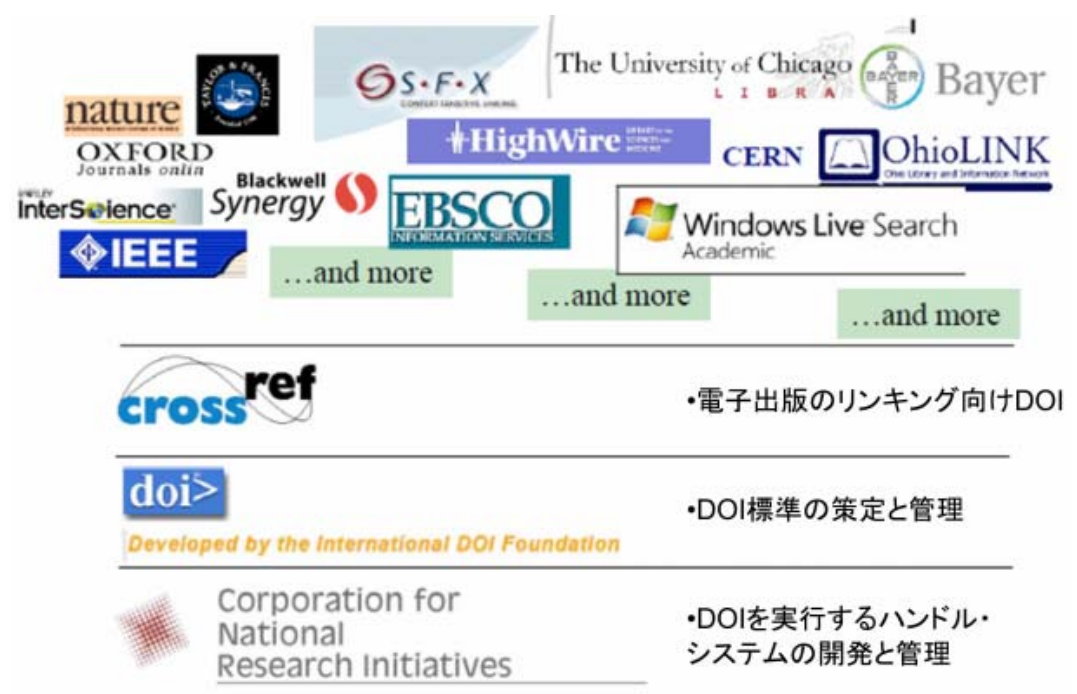

図2 CrossRef/DOI コミュニティ

トの利用許諾があれば，常に何らかの形でフルテ キストに到達できることです。その裏では, URLと は異なり, コンテンツに単に直接リンクするので はなく, 現在のアドレスをDOIリゾルバー（図3の 中央のボックス）に問い合わせています。

DOIは, 面白いことに, 初期段階には「縁の下の 力持ち」と言われていました。DOIは裏側で機能し ているということですが, 実際その通りなのです。 私たちは常に,DOIを出版インフラストラクチャー として扱っており,研究コミュニティやエンドュー ザーに積極的に宣伝してきませんでした。しかし 最近, これが変わりつつあります。研究者がDOIの 存在に気づいて, 自ら利用することが多くなって きているようです。プリンストン大学化学部の院
生が書いたブログを紹介しましょう。「DOIは私の 悩みを解決してくれるか?」というのがタイトル で, 彼女の悩みは, 自分が書いた論文の参考文献 からのリンクが, リンク切れになってしまうこと でした。彼女は, 実際にDOIを使って参考文献リン ク生成を行っており,「DOIはジャーナル論文にとっ ての自動誘導装置のようなもので, コンテンツが Web上のどこにあっても, DOIで探しだすことがで きる」と書いています。そしてこれが, DOIが他の リンク方法, またOpenURLとも違うところです。 DOIは永続的な識別子なので, DOIを論文の参考文 献に記述すれば永続的に機能します。これがURL と違う点です。

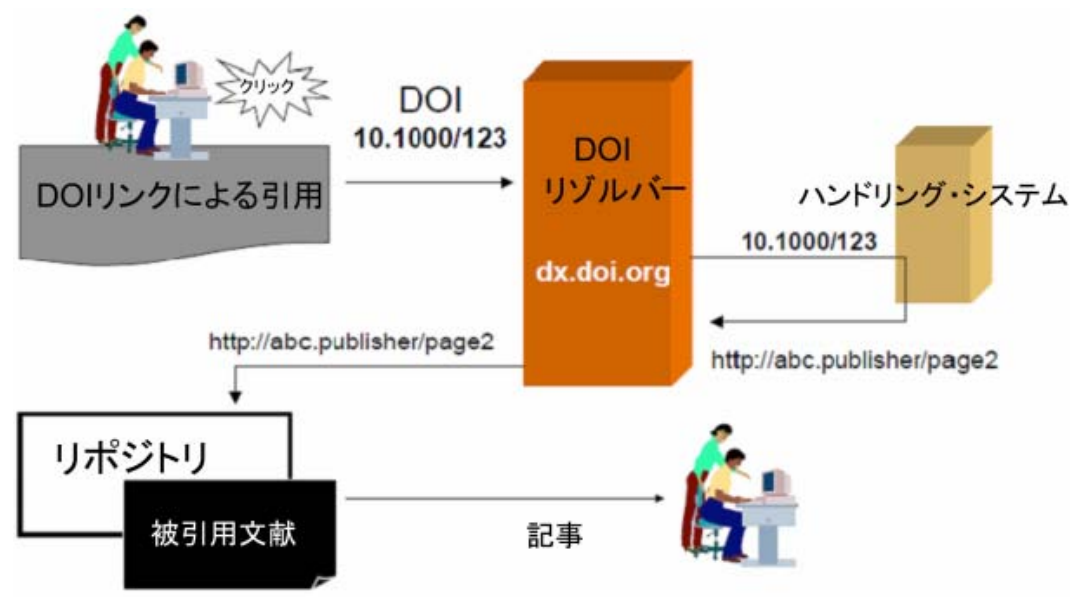

図3 CrossRef/DOI リンキング 


\section{CrossRefの詳細}

\section{1 垣根を越えて}

CrossRefという組織についてもう少しお話しし ようと思います。すでにお話ししたように,CrossRef は, 学術出版業界向けの優れた共有デジタル・イ ンフラストラクチャーであり, 最大のDOI登録機 関です。出版社や他のコンテンッ・プロバイダー がメンバーになっている非営利団体でもあります。 私たちは，利益を上げようと躍起になることはあ りません。CrossRefは営利団体ではないからです。 当然, 経費は必要なので, 参加機関から会費と DOI登録料の両方を徵収しています。しかしこう いった費用は，基本的に出版社の支払い能力に合 わせてあり，その幅は, 年会費で 250 ドルから 3 万 ドルと非常に広く設定されています。DOI1件当た りの登録費用はその都度の支払いで, 新規コンテ

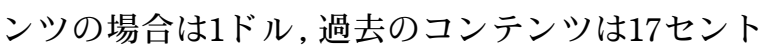
になります。

J-STAGEに参加している出版社は, 必ずしもこ ういったことを知っている必要はありません。そ れは, J-STAGEの参加出版社は, J-STAGEがスポン サーとなって, CrossRefに正規に参加しているこ とになるからです。

会員制組織として私たちが目指しているのは, 出版者の種類の違いを乗り越えることです。 CrossRefには非常に幅広い出版者が参加していま す。商業出版社, 学会, 非営利団体, 大学出版会, さらには, 学術的コンテンツを作成している機関 レポジトリも, CrossRefに参加できます。

CrossRefは科学・技術・医学分野から始まりまし たが，今では非常に幅広い分野のコンテンツを対 象としています。CrossRefのネットワークに関連 するコンテンツを実質的に定義すると, 研究志向 で, 学術的かつ専門的なコンテンツということに なります。CrossRefは, 36か国のコンテンツ・プロ バイダーを代表しており, 参加国数は増加してい ます。

CrossRefがこれほど成功している理由は, ビジ ネスとは無関係であること, そしてユーザーの支 払いの有無に影響されないためと考えています。 研究コミュニティで現在,非常に大きな議論となっ ているビジネスモデルの話題については, CrossRef は完全に中立の立場であり, オープンアクセスの 推進などとも関係していません。CrossRefが行う のは, 読者が出版社の入り口に確実に到達できる ようにすることであり, 認証方法や, 支払いの必
要性, さらにコンテンツがオープンアクセスかど うかといった問題は, 完全に出版社次第です。そ のため,CrossRefはどのような種類の出版社にとっ ても魅力的であり, 誰の脅威にもなりません。

出版社の垣根を越えて機能するこのモデルは, ネットワーク効果という点で非常に強力です。な ぜなら, 出版社や第三者機関がそれぞれ, 多数の 二者間交涉を行う必要がない組織構造があれば, このネットワークはさらに広がるからです。 CrossRefは組織として,このような構造を用意し ています。出版社は, CrossRefと参加出版社として の契約を一度結べば，他の参加機関すべてと相互 リンクする権利が与えられます。たくさんの組織 と個別に相互リンク契約を締結する必要がないの です。

また, そのほかに, CrossRefが参加機関の役に立 つ例として, CrossRefの活動に積極的に参加して いる出版社は,CrossRefを新しい出版テクノロジー の共同開発の場として利用しているということが 挙げられます。

\subsection{CrossRefの技術的側面}

技術的な面についてですが, CrossRefがリンク の持続性を目的としてDOIを提供していることは, すでにお話ししました。また, CrossRefはOpenURL との連携機能も提供していますが, これは後から ご紹介したいと思います。おそらく，あまり知ら れていないのは, CrossRefのメタデータ・データ ベースの価值ではないでしょうか。CrossRefのサー ビスのうち, DOI登録に関する部分は, 二次的なも のと考えています。CrossRefはコンテンツを発見 し，リンクを提供するサービスです。そのため, CrossRefのサービスを利用し, DOIを登録する出版 社は, そのメタデータを1つのデータベースで管理 しています。このデータベースには, 図2で示した ような組織がすべてアクセスしており, リンキン グの際にコンテンツがより発見されやすくなって います。この後, システムへのさまざまなアクセ ス方法を提供することで, CrossRefが技術的な障 壁を低くしていることをお話ししたいと思います。 ここでご説明したいのはアクセス誘導について です。通常, アクセスをコンテンツに誘導するこ とを考える場合, マーケティングや検索エンジン 最適化などで, コンテンツが発見されやすくする ことを考えます。しかしCrossRefは違った形で, ア クセス誘導メカニズムとして機能しています。こ れは, CrossRefは裏側にあって, 出版社のコンテン 
ツへの引用やリンクをすべて正しく機能させ,ユー ザーがコンテンツに簡単にたどり着けるようにし ているからです。

その技術的な詳細には触れませんが, CrossRef のシステムを利用する出版社は, 基本的に $2 \supset$ の とを行っています。まず, 出版社は基本的な書誌 情報メタデータとDOIをデポジットして, 他のサ イトから出版社のサイトへのリンクを可能にして います。また, 出版社はデータベースに参考文献 のDOIを問い合わせて, DOIベースのURLを付与し た参考文献を作成します。こうすることで，ユー ザーエクスペリエンスに付加価值を与えられるの で, 出版社にとって, また別の価值あるサービス なのです。

\subsection{DOIの利用}

DOI の利用例として，いくつかのスクリーン ショットをお見せしたいと思います。一般的に, DOIは記事に付与されており, 基本的な書訫情報 の一部になっています。『Proceedings of National Academy of Science』では, DOIがヘッダー情報の一 部として表示されています。DOIは, 本の章ごとに も付与されていますし, Blackwell Synergy上の ジャーナルにも付与されています（図4）。また, DOIはJ-STAGEに登載されている,『IPSJ Digital Courier』の記事にも付いています。DOIがエンド ユーザーから見えるようになっていることも増え ています。ベストプラクティスによって, DOIが記 事の識別情報の一部として, 記事の最初のページ
に掲載されているからです。また, CrossRefのDOI が記事中の参考文献リンクに用いられている場合 もあり（図5）, 今では多くの出版社がユーザーに さまざまなリンクオプションを提供しています。 CrossRefリンクが他と違う点は, 実際に出版社の サイトにユーザーを誘導し, ライセンスがあれば フルテキストに直接アクセスする機能を提供して いるのはCrossRefだけだということです。JSTリン ク・センターの場合には, CrossRefリンクをオプ ションの1つとして表示しています（図6）。

DOIは,ブログなどあらゆる種類のWebリソース で利用されるようになってきています。つまり， DOIはジャーナルで利用されるだけとは限らない のです。DOIは, あらゆるオンライン環境で, 学術 文献の引用方法として推奨されるようになってき ています。また, DOIシステムは, さまざまな参考 文献管理，または引用管理のソフトウェアと連動 しています。日本でどれくらい有名かわかりませ んが，米国ではRefWorks とProCiteが研究者に幅広 く利用されています。

\section{4. 成長するCrossRef}

\subsection{CrossRefの最新動向}

CrossRefは毎日1万4,000件のDOIを登録していま す（訳注：2007年6月現在)。すでにお話ししたとお り, 書籍, 標準規格, 会議録, 画像, 図, 主な参考 資料, データセットなど, さまざまな種類の資料 について登録の申し込みがあります。また, 出版

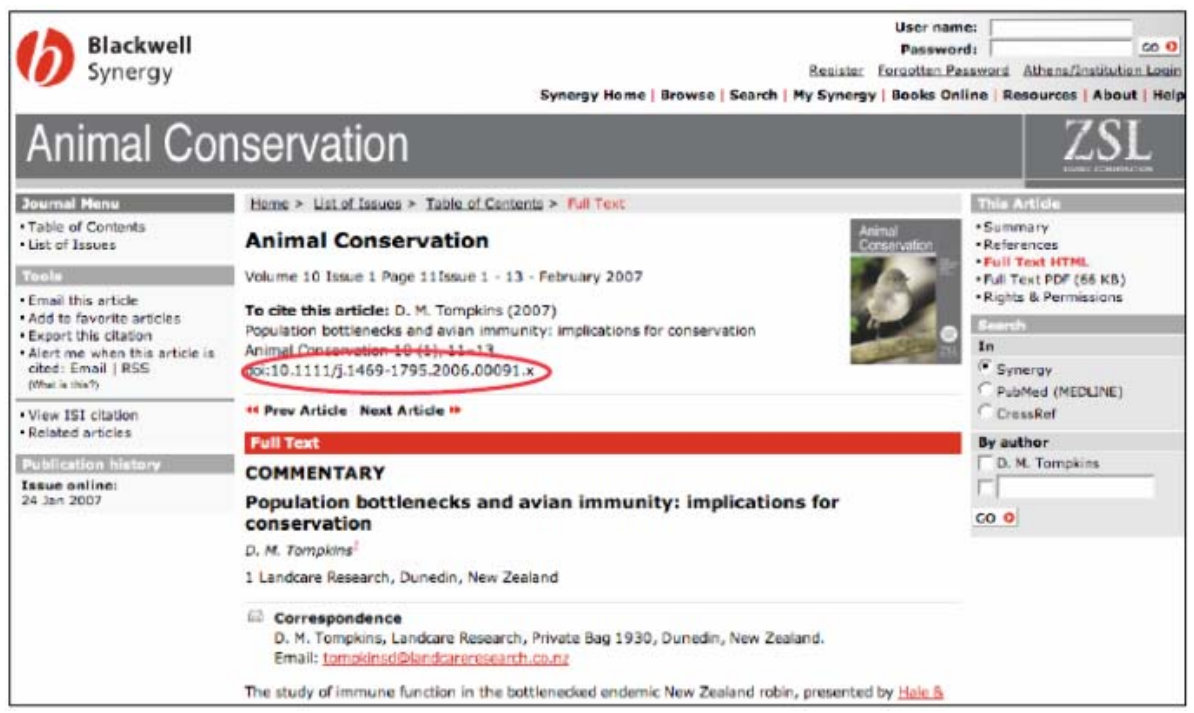

図4 Blackwell Synergyの記事に付与されたDOI 


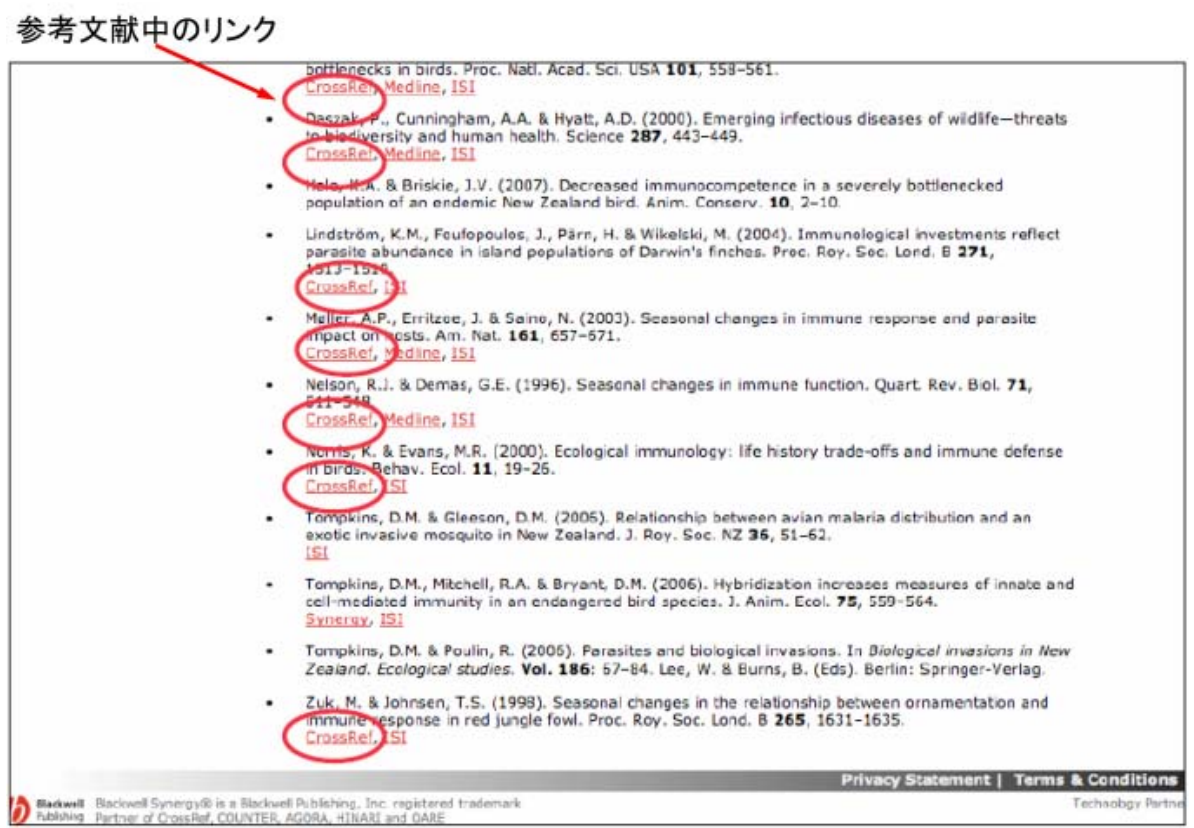

図5 Blackwell Synergyの記事の参考文献

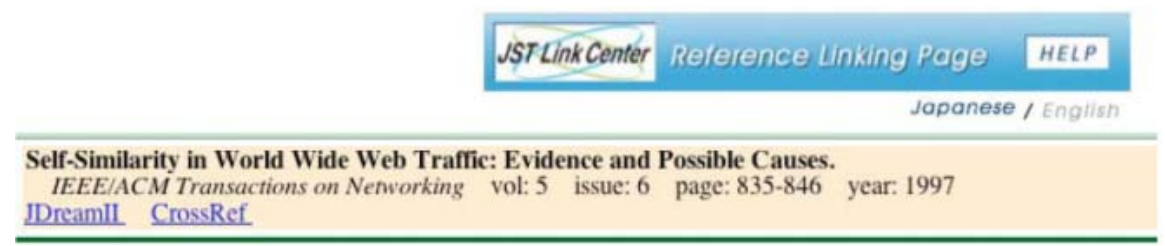

図6 JST リンクセンター画面でのCrossRefリンクの表示

社などの参加機関は数千機関にのぼります。こう いった統計データを時系列的に見ると,CrossRefが 引き続き安定した成長の過程にあることがわかり ます。

J-STAGEについては,198の学会出版社がJ-STAGE 経由で，14万4,000件以上のDOIを登録しています （訳注：2007年5月現在）。CrossRefは, 参加出版社 にアクセス数を知らせていますが，これは，出版 社のコンテンツへのリンクがクリックされた数で, 2007年6月は, J-STAGE関連のDOIへは3万7,500回の クリックがありました。

CrossRefシステムに登録されているコンテンツ の内容や，そこから生まれる包括的な相互リンク のネットワークについては, 今もジャーナルが中 心です（図7）。ジャーナルは他の種類のコンテン ツよりも早くオンライン化を開始し, その普及も 早かったことが理由の1つです。しかし, CrossRef で現在最も成長している領域は，書籍です。以前 にも増して, CrossRefメンバーが書籍をデジタル

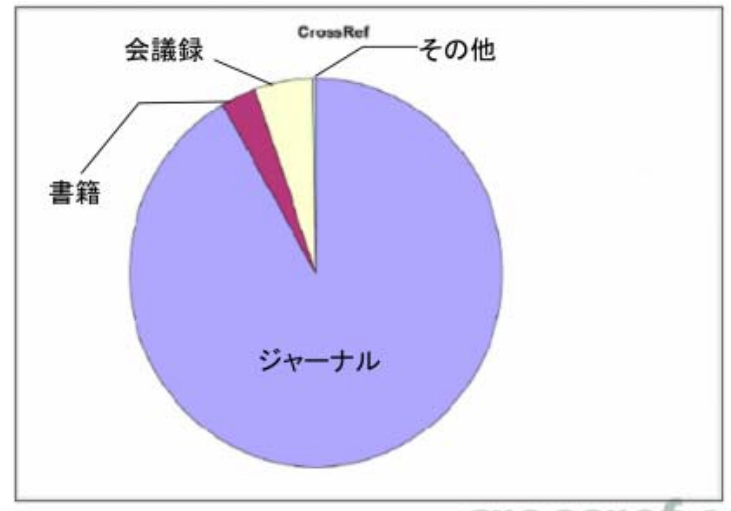

crossref.

図7ＣrossRefのコンテンツの種類

化し，それにDOIを付与する傾向が強くなってい ます。

DOIを付与している書籍には, 『オックスフォー ド英国人名辞典 (Oxford Dictionary of National Biography)』があります。これには6万5,000件の情 
報が登載されており，それぞれの項目にDOIが付 いています。CrossRefに登録されている書籍の多 くでは, 章の階層, あるいはもっと細かい階層に DOIを付与しています。つまり, 研究者が引用しょ うとする階層でDOIを付与するということです。ま た, ジャーナルの記事から補足情報へリンクする 際にも，DOIを利用することが多くなってきてい ます。さらに別の例としては, 出版社がDOIを論文 記事内の補足的な眓に付与して,この図へリンク する際にDOIを使用する場合があります。

昨日講演を行ったあるセミナーで, 質問があり ました。質問者が少し混乱している面もあるので すが, それは「補足情報はいつでも, ジャーナル 記事の一部として登録されるのですか」という質 問です。答えは「どちらもあり得ます」です。例 えばProtein Data Bankなどの科学データベースのな かには, ジャーナルは発行せず, DOIをデータベー ス内のレコードに付与するだけのものもあります。 つまり, 1つのDOIを基本的に 1 つ項目, ここでは タンパク質に関する非常に詳細な記述に対して付 与しているのです。一方で, 論文にDOIを付与し， さらに論文内の項目にもDOIを持たせるという,よ り階層的な方法を採用している場合もあります。

また他の大きな動向としては, 出版社がジャー ナルのバックファイルのデジタル化を進めている ことがあります。日本でも行われていると聞いて いますが, アーカイビング・プロジェクトや,アー カイブ資料のデジタル版がCrossRefに登録されて います。おそらく, CrossRefのDOIのうち, 約40万 件が19世紀以前のコンテンッに付与されています。 DOIの分布の中で,一番古いものが1665年に発行さ れた, 最初の査読付きジャーナルとされている 『Philosophical Transactions of the Royal Society』の中 に見つかるのは興味深いことです。同時に非常に 魅力的なことは, こういった古いコンテンッのオ ンライン化が進み, 出版社が次々にすべてのバッ クファイルを登録するようになると, 古いコンテ ンツもリンクでたどれるようになり, CrossRefの ネットワークが過去に向かって広がっていくとい うことです。

\subsection{DOIのデポジットとクリックの統計データ}

ここでCrossRefのさまざまな統計データを紹介 しましょう。DOIのデポジット数が 1 日 1 万 4,000 件 であることはお話ししましたが (図8)，ここでは 図8の下の表に注目したいと思います。これは「マッ チ率」と呼ばれるもので, CrossRefの全ユーザー
が, 目的のコンテンツを見つけられた場合の成功 の割合を示しています。ユーザーが参考文献や書 誌情報のメタデータに関するクエリをCrossRefに 送り, DOIが返ってきた場合, 「成功」と数えてい ます。わずか 6 年か 7 年の間で, 学術コミュニケー ションの世界にいる人が, CrossRefを通じて, 探し ているコンテンツの $50 \%$ 近くを入手できるように なったのは, 非常に画期的なことだと思います。 このマッチ率は, 明らかに成長を続けています。 ですから,ユーザーが見つけられないコンテンッ は, まだデジタル化されていないか, システムに 登載されていないということになります。

私たちが参加機関に提供している別の統計には, DOIのクリック数があります。CrossRef経由での DOIアクセス数は, 1か月当たり1,600万回です（図 9)。J-STAGEの場合は, CrossRef経由でJ-STAGEに 到達しているアクセス数も, 過去6か月で大きく増 加しています。

\subsection{OpenURLとの連携機能}

OpenURLについてもお話ししたいと思いますが, それは, DOIとOpenURLの関係について䛊解がよ くあるからです。CrossRefは, 非常に多くの図書館 と協力関係にあります。図書館がローカルのリン ク・リゾルバーのベースURLをCrossRefに登録する と, その図書館内のユーザーがDOIをクリックす るたびに,CrossRefはそのDOIをローカルのリンク・ リゾルバーにリダイレクトします。つまり，この 場合のDOIリンクは, ユーザーのために適切な情 報源のリストを作成しているのです。この点では, OpenURLによって, CrossRefの参加機関は自動的 にCrossRef DOIを使うことができるようになって います。

CrossRefはSerials Solutions やSFXなど8つのロー カル・リンキング・ソリューションと提携してい ます。リンク・リゾルバーを登録するために, 図 書館がCrossRef と連携して行うサービスは, 完全 に無料であり, 公開されています。ただし, すで に述べたように, 図書館はリンク・サーバを導入 しているので, この場合, ユーザーがDOIをクリッ クする際に, cookie (クッキー) をユーザーのコン ピュータか機関の環境に設定する必要があります。 cookieがCrossRefのサーバに, DOIをローカル・リ ンク・サーバにリダイレクトするようアラートを 発します。これが連携機能の一部分です。

他の連携機能は, CrossRefが保有するメタデー タに関して導入されています。OpenURLに実装す 


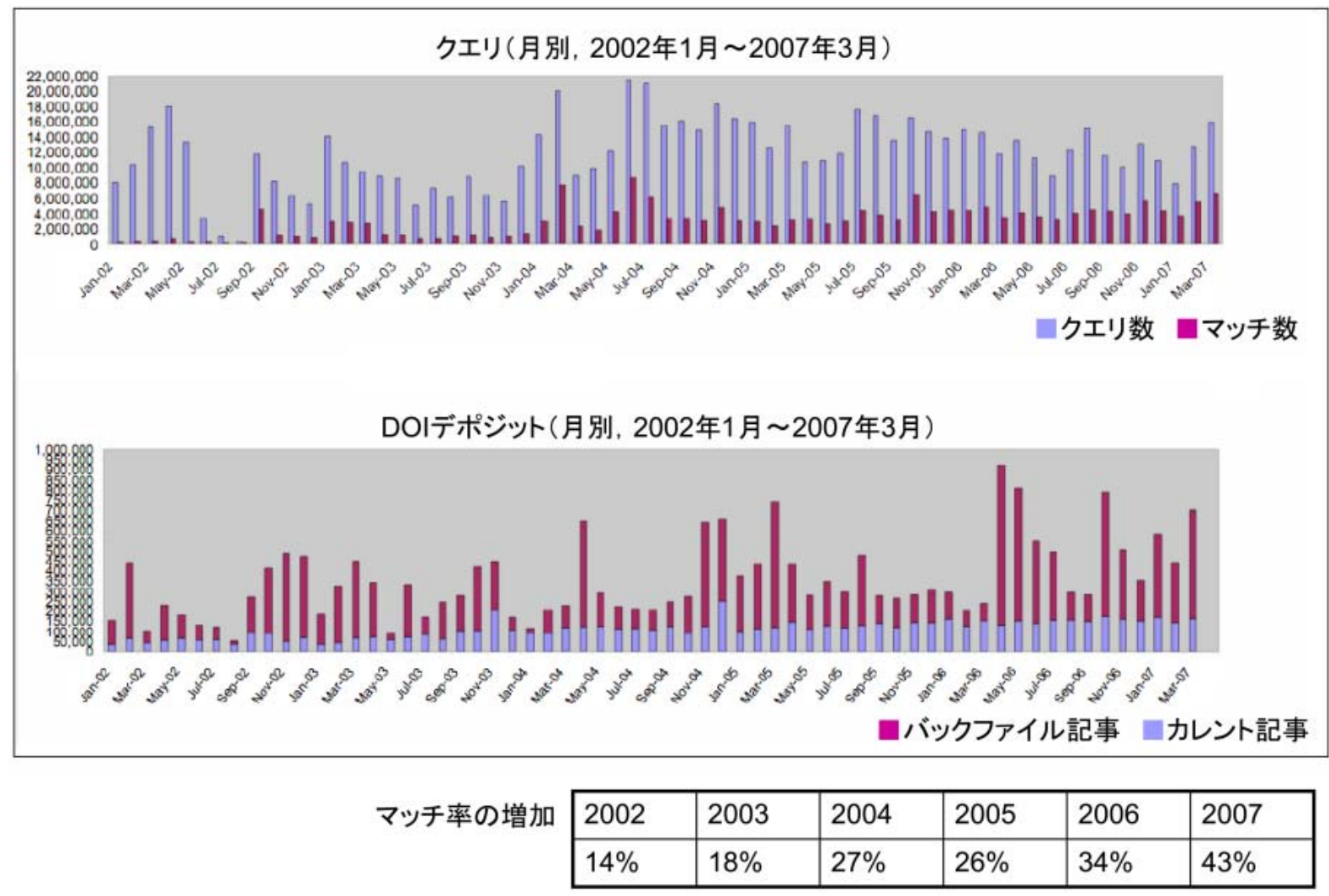

図8 クエリ数, マッチ数, デポジット数とマッチ率の推移

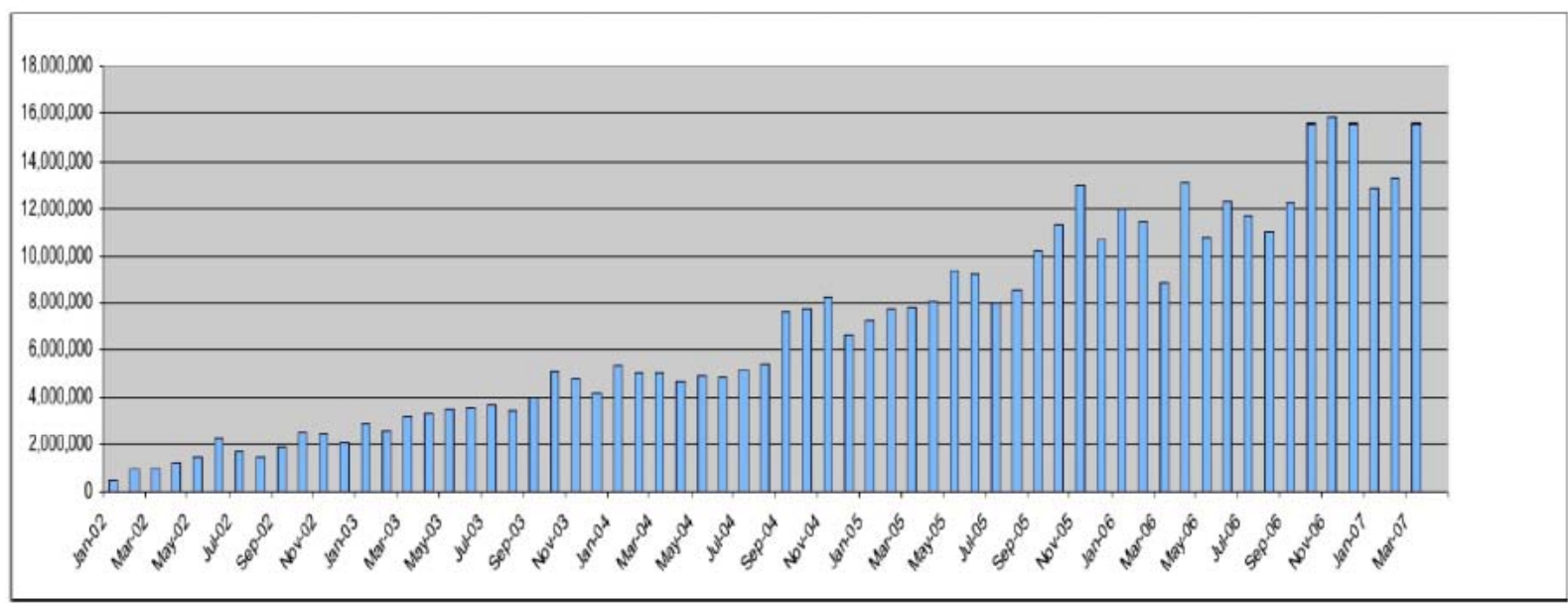

図9 DOIクリック数（月別，2002年1月～2007年3月）

ることのできる, CrossRefのメタデータ・データ ベースについて，すでに紹介しました。記事単位 のメタデータがCrossRefから抽出されますが, こ れがあれば,どんなリソースでも, OpenURLはそ の機関内から見つけられます。

ここで図を1枚お見せします（図10）。これは， ユーザーが参考文献のリンクをクリックした場合 を示しています。通常, クリックするとDOIリゾル
バーを経由しますが,この場合はそうなりません。 それは，これがOpenURLの場合だからです。DOI リンクは, ローカル・リンク・サーバにリダイレ クトされ，その機関で利用できるオプション（こ の場合はSFXメニューですが) が表示されます。つ まり, CrossRefとOpenURLは, 本当の意味で補完的 な技術であって , 決して競合することはないのです。 実は, CrossRefでは, 同じことをするのに多くの 


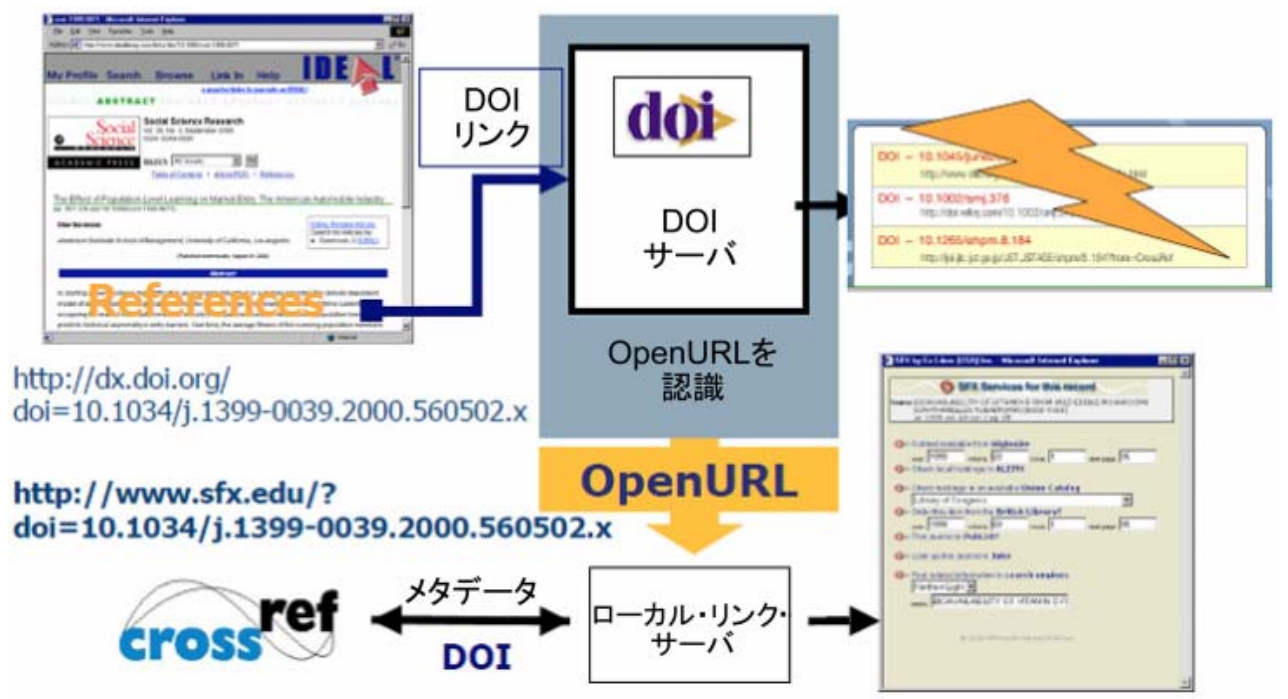

図10 CrossRefを補完するOpenURLリンキング

方法があり, CrossRefを利用する出版社もまたリ ンクオプションの表示方法を用意しています。し かし, 出版社がコントロールすることは, 図書館 がコントロールすることとは同じではありません。 そして, これが「マルチプル・レゾリューション」 と私たちが呼ぶ, 最も成長している分野なのです。 この場合, DOIは1つのリソースだけをリンクする ためでなく, リソースのメニュー全体をリンクす るために用いられています。つまり, 記事が複数 のプラットフォーム上にある場合, 出版社は読者 に, その記事へのリンク1つだけではなく, 関連情 報へのリンク, あるいはジャーナルのホームペー ジへのリンクも提供したいと考えています。これ は, CrossRefでも可能です。つまり, 1対1のリンク だけでなく, ロケーションやサービスのメニュー を示すリンクということです。

ですから，例えば『Russian Journal of Earth Sciences』の場合には, その記事は American Geophysical Unionや, The Geophysical Center RASな ど, 複数のプラットフォームで閲覧することがで きます。ユーザーはオプションの中から, 自分自 身で選ぶのです。同様に, 同じ情報をドロップダ ウン・メニューとしても提供できます。つまり,ユー ザーがリンクの上にマウスを合わせれば,メニュー がポップアップして，このDOIに関連する記事の うち, どのプラットフォームに移動したいかと聞 いてきます。コンテンツによって違いますが, OpenURLメニューについては,図書館がコントロー ルするオプション・メニューと, 出版社がコント ロールするオプション・メニューの間に, かなり
の重複があるのです。多くの出版社がこういった 種類のマルチリンクを持つようになってきていま す。

\subsection{Forward linking}

CrossRefのインフラストラクチャーに私たちが 構築した他の機能には,「Forward linking」あるい は, 単に「被引用リンク」と呼んでいるものがあ ります。これは, 他のどのコンテンツが, そのコ ンテンツを引用しているかという情報です。出版 社はこれを一時期提供していたことがあり, 他の プラットフォームでこれを見たことがあるかも知 れません。しかし通常はそのプラットフォームの 環境の中で行われていました。出版社の場合は, 同じ出版社が発行した他の記事が, その記事をリ ンクしていることを表示しますが, CrossRefでは これを, 出版社を横断するプラットフォームで実 現している点がュニークです。

Forward linkingはまだ比較的新しい機能で, CrossRef参加出版社のうち, J-STAGEなど一部の出 版社が参加しています。現在のところ，1,500万通 りの被引用関係が生成されています。このサービ スの良い点は, 自動アラート機能があることです。 出版社が新規に参加して, 被引用情報を外部プラッ トフォームの一部としてユーザー向けに表示させ たいとします。その場合, 出版社は, 新しい参考 文献がデポジットされた場合に自動アラートを受 け取ることができます。図11の囲み部分に,「JST Link Center Cited」というオプション表示がありま す。これがCrossRefの機能で, この記事を引用して 
いる，CrossRef上の他の記事に移動できるように なっています。これが, CrossRefで現在成長してい る領域です。

\section{CrossRefの新サービス}

\section{1 非XMLベースのオプション}

ここまで,技術的障壁を低くするためのCrossRef の取り組みについて強調してきました。さらに私 たちはその一環として, CrossRefシステムに非常 に簡単なインターフェースを用意しています。

非常に大規模な出版社（その多くはCrossRefの 参加機関ですが) は, さまざまなXMLべースのイ ンターフェースを使って, CrossRefとやりとりを しています。一方, CrossRefは, 非XMLベースの才 プションも提供しており,これを「マニュアルDOI 登録フォーム」と呼んでいます。小規模な出版社, 例えばジャーナルを 1 誌しか発行していなくて, XMLタグ化の作業を避けたい学会などは, 基本的 な書誌情報を入力するだけでDOIの登録ができま す。必要な書誌情報は，タイトル，ジャーナルの DOI, URL, print ISSN, 巻, 号, ページなどですが, 一部の項目は任意入力です。フォームは非常に簡 単です。DOIの登録としては効率的ではありませ んが, 非常に利用しやすくなっており, XML形式 のデポジットファイルをシステムが自動的に作成
するようになっています。

同様にクエリの場合も，通常は大量のXML形式 の参考文献が必要ですが, CrossRefのWebサイトに は，カット・アンド・ペースト方式のフォームが あります。そこに参考文献をカット・アンド・ペー ストするだけで，DOIが付いた形式で参考文献が 表示されます。このフォームはCrossRefのWebサイ トに数か月前に設置されましたが, 研究者がこの フォームでDOIを検索し, 執筆の早い段階で論文 に取り込むという利用方法が増えているようです。 つまり，出版社だけでなく，エンドユーザーや論 文著者も, DOIを参考文献につけるのが自分たち の責任だと考えているのです。

\subsection{CrossRef Webサービス}

CrossRefにすでにある, 出版社の垣根を越えた 連携機能をさらに強化するために，いくつかの取 り組みを行っています。新しい取り組みの 1 つは, 出版社横断メタデータの流通で, これによって, CrossRefメンバーがCrossRef以外のパートナーにメ タデータを提供する方法として, CrossRefを選択 できるようになっています。私たちはこれを 「CrossRef Webサービス」と呼んでいます。このサー ビスでは，メタデータ全体を，そのデータを必要 とするサーチエンジンなどの第三者機関に提供し ます。一方，出版社にとってのメリットは，この

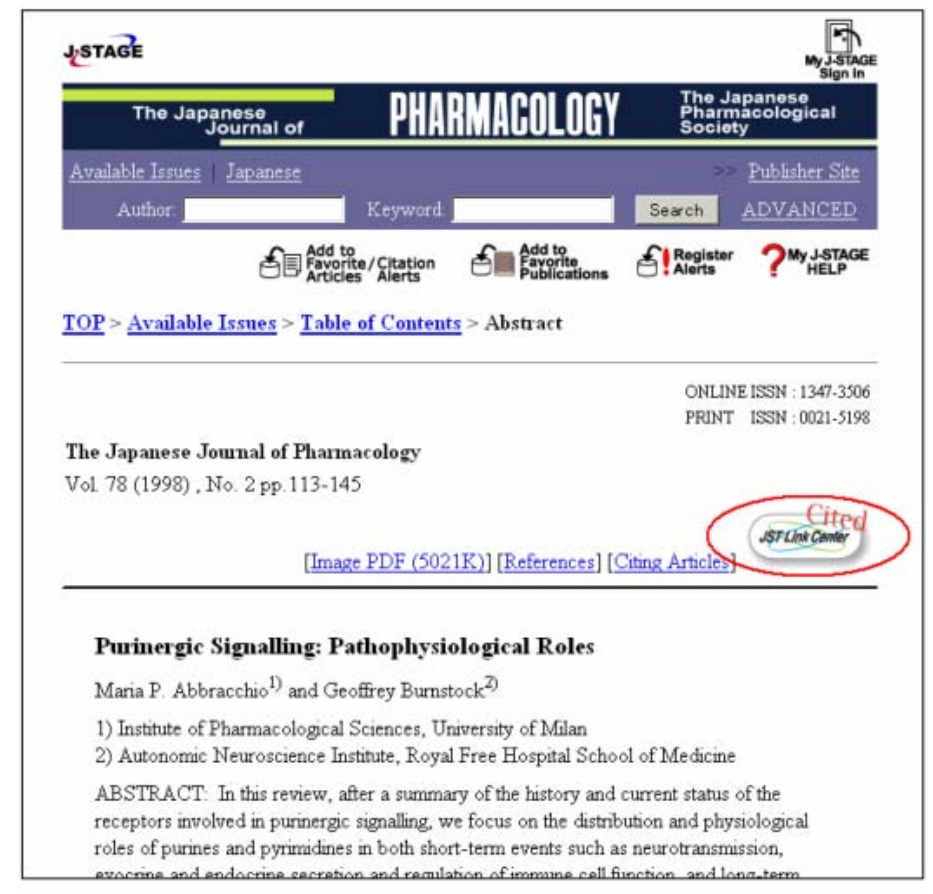

図11 J-STAGE登載記事に付与された「JST Link Center Cited」の表示 
サービスでは, 出版業界の利害関係を考慮した上 で，メタデータの使用条件に関する標準的な文案 が作成してあることです。これは, 出版社が利用 するか選択できるオプションになっています。

CrossRef Webサービスによる最初のパートナー は,マイクロソフトでした。私たちは, Windows Live Academicの構築に際して, マイクロソフトと非常 に緊密な連携を行いました。マイクロソフトがメ タデータを必要とする理由は数多くありますが, 私たちがマイクロソフトに提供したデータは, マ イクロソフトのWeb巡回プログラムに, 出版社サ イトでのインデキシングが必要なコンテンツの所 在を知らせます。プログラムが, 何をインデック スすべきか, インデックスの何を更新すべきかを 知るのに役立つのです。これは, エラーの起こり やすい, 自動メタデータ抽出の代わりになります。

\section{3 剽窃検出システム}

もう1つの新サービスは, 剽筀検出システムで, ちょうどパイロット版を立ち上げようとしている ところです（訳注：このサービスは「CrossCheck」 という名称で提供予定)。これは投稿された論文が 剽窃でないことを確認するためのものです。編集 の段階で, 出版社は必要に応じ, このサービスの 発表論文データベースで, 投稿論文と同じものが ないか確認できます。このアイデアは, CrossRefに 参加する出版社のニーズから生まれたものです。 出版社は, 剽窃が問題になりつつあると考えてい ますが, 発表される論文数は増えており, ある論 文が本当にオリジナルかどうかを確認するのは, より難しくなってきているためです。こういった 技術は, Text Fingerprinting (テキスト指紋認識) と 呼ばれています。このシステムでは, 出版社横断 データベースが作成されています。その中から一 致する文字列を探し, 出版社に重複テキストのレ ポートが提供されます。私たちは，これが参加機 関にとって非常に便利なツールになると考えてい ます。

iThenticateというシステムをご存じでしょうか。 また米国では, 論文を提出する大学生が使ってい るTurnitinというシステムもあります。大学の多く は学生に対して, Turnitinで自分の論文が盗作でな いことを証明し，提出時にはその証明としてTurnitin のレポートを添付することを求めています。大学 生による論文の盗作は, 米国で大きな問題になっ
ています。iParadigmsは, TurnitinとiThenticateを運 営している会社ですが, iParadigmsが私たちと提携 したいと考えた理由は, 私が先に述べたのと同じ 理由です。iParadigmsはCrossRefと交涉して1つの契 約を結ぶだけで, CrossRefに参加しているすべて の出版社と提携できるからです。非常にたくさん の個別契約について交涉する必要がありません。 そしてその結果, iParadigmsは, 必要なコンテンツ にインデックスを付与して, 剽窃検出システムの 中心となるデータベースを構築することができる のです。

\section{4 他の新サービス}

ほかにもいくつか新サービスを開発しようとし ていますが, そういったサービス開発を行う理由 は, CrossRefが国際的な出版コミュニティとの間 に築いてきた協力関係を強化し, 研究者や出版社 の役に立つにはどうすればよいかと考えているか らです。

出版社に参加を呼びかけているものの 1 つに, CrossTech Blogがあります。これは, 新しい出版技 術について議論し, 経験やべストプラクティスを 共有するためのフォーラムです。また, 私たちは さまざまな会議を開催しており, さらにメンバー が参加できるいろいろな委員会を設置しています。

\section{6. 結論}

出版社との連携をもとに, リンク切れの問題を DOIを活用して解決したことや，相互リンクされ た情報ネットワークがうまく構築されて, 今でも 成長を続けていることをお話ししてきました。 CrossRefは, ネットワークを成長させる手助けに 力を注いできましたが, その際の方向性は, 多く の学術出版社の参加, コンテンツの多様化, 過去 のコンテンツのカバー, 被引用リンク, 細かい階 層でのDOI付与などいくつかあります。また, DOI がコンテンツの一部分として付与されることが増 えると考えていますし, マルチプルリンキングに ついてもお話ししました。一番興味深いことは, 研究の表現方法が豊かになり, テキストがデータ セットなどの関連情報と切れ目なくつながるよう になることです。DOIを利用した学術発表が, ます ます増えると考えています。 